\title{
Effect of parity, days in milk, and milk yield on detailed milk protein composition in Mediterranean water buffalo
}

\author{
V. Bonfatti, ${ }^{\star 1}$ M. Gervaso, ${ }^{\star}$ A. Coletta,† and P. Carnier* \\ *Department of Comparative Biomedicine and Food Science, University of Padova, Viale dell'Università 16, 35020 Legnaro Padova, Italy \\ †Italian Water Buffalo Breeders Association, Via C. Battisti 68, 81100 Caserta, Italy
}

\begin{abstract}
The effects of some nongenetic factors on milk protein fraction contents and relative proportions were estimated in 606 individual milk samples of Mediterranean water buffalo. Content of $\alpha_{\mathrm{S1}}$-casein $(\mathrm{CN}), \alpha_{\mathrm{S}^{2}} \mathrm{CN}, \beta-\mathrm{CN}, \gamma-\mathrm{CN}, \kappa-\mathrm{CN}$, glycosylated $\kappa-\mathrm{CN}$ (glyco-k-CN), $\alpha$-lactalbumin, and $\beta$-lactoglobulin was measured by reversed-phase HPLC. Relative contents of $\alpha_{\mathrm{S} 1}-\mathrm{CN} \%, \alpha_{\mathrm{S} 2}-\mathrm{CN} \%, \beta-\mathrm{CN} \%$, and $\kappa-\mathrm{CN} \%$ were, respectively, $32.1,17.1,34.5$, and $15.7 \%$, whereas $\gamma-\mathrm{CN} \%$ accounted for $0.6 \%$ of total casein content. Increasing total casein content in milk would result in a greater proportion of $\beta-\mathrm{CN} \%$ at the expense of all of the other major casein fractions, especially of $\kappa-\mathrm{CN} \%$. Values of $\alpha_{\mathrm{S}_{2}} \mathrm{CN} \%, \beta-\mathrm{CN} \%$, and $\gamma$-CN\% tended to decrease with parity, although their variations were not significant, whereas $\alpha_{\mathrm{S}_{1}} \mathrm{CN} \%$ and glyco-k-CN\% showed the opposite trend. Contents of most protein fractions showed the typical trends observed for milk components as lactation progressed, with high contents in early lactation, a minimum in midlactation, followed by a gradual increase toward the latter part of lactation. Values of $\alpha_{\mathrm{S}^{-}} \mathrm{CN} \%$ increased during lactation, whereas $\alpha_{\mathrm{S} 2}-\mathrm{CN} \%$ decreased. The proportion of $\beta-\mathrm{CN} \%$ had its maximum value between 60 and $160 \mathrm{~d}$ of lactation, followed by a decrease, whereas $\kappa-\mathrm{CN} \%$ had its minimum value in early lactation $(<60 \mathrm{~d})$ and remained relatively constant in the period of mid and late lactation. Glyco-к$\mathrm{CN} \%$ and $\beta$-lactoglobulin\% decreased in the first part of lactation, to reach their minimum values in midlactation, followed by an increase. Milk of top-producing buffaloes, compared with that of low-producing ones, had a significantly greater value of $\beta-\mathrm{CN} \%$ and glyco- $\kappa-$ $\mathrm{CN} \%$, and lower proportion of $\alpha_{\mathrm{S}_{1}} \mathrm{CN} \%$. The possible effect exerted by protein genetic variants in affecting variation of milk protein fraction contents and relative proportions should be further considered to better get insight into buffalo milk protein composition.
\end{abstract}

Received October 26, 2011.

Accepted March 24, 2012.

${ }^{1}$ Corresponding author: valentina.bonfatti@unipd.it
Key words: casein fraction, milk protein composition, lactation, water buffalo

\section{INTRODUCTION}

Studies on variation of major milk proteins are of interest because individual caseins and whey proteins affect the nutritional value and technological properties of milk as a result of both qualitative and quantitative variations (Wedholm et al., 2006; Bonfatti et al., 2010a). Contents and composition of caseins and whey proteins of bovine milk exhibit considerable variation, being influenced by the age of cow, DIM, health status (Kroeker et al., 1985; Ng-Kwai-Hang et al., 1987), and genetic effects (Heck et al., 2009; Bonfatti et al., 2010b).

Buffalo ranks at the second position for worldwide milk production and the buffalo population in Italy has increased considerably in the last 50 yr (FAOSTAT, 1969-2009). This increased economic importance can be ascribed to the lack of regulations based on milk quotas, which restrict cow milk production in Europe, and to the large market demand of Mozzarella cheese (de Stefano, 2004). Because of the consumer demand for buffalo dairy products, in Italy, the price of buffalo milk is twice as high as the price of cow milk (ISMEA, 2009).

In contrast with the large number of studies on nongenetic and genetic effects affecting protein fractions in bovine milk, few and conflicting results are available for buffalo milk protein composition. To date, studies on buffalo milk protein fractions have been conducted using samples of few animals (Addeo, 1979; D'Ambrosio et al., 2008; Ariota et al., 2009) or using cow milk proteins as calibration standards (Feligini et al., 2009; Buffoni et al., 2011).

Despite the worldwide spreading of the buffalo, no studies have been carried out on the variation of detailed protein composition of buffalo milk. Aims of this study were to quantify the major milk protein fractions for a large sample of animals and to investigate the effects of some nongenetic factors on the content and composition of buffalo milk proteins. 


\section{MATERIALS AND METHODS}

\section{Milk Sampling}

Single test-day milk samples of 606 Mediterranean water buffaloes were collected in 14 commercial herds (Campania, south of Italy) from October 2010 to January 2011. One composite sample of milk collected during the morning and the consecutive evening milking was obtained for each animal. To prevent proteolysis, milk was immediately frozen after collection and stored at $-20^{\circ} \mathrm{C}$ until the transfer to the Department of Animal Science of the University of Padova (Legnaro Padova, Italy). Samples were stored in dry ice during the transfer and kept at $-40^{\circ} \mathrm{C}$ until reversed-phase HPLC (RP-HPLC) analysis. Parity number, DIM, day of test, and milk yield were supplied by the Italian Water Buffalo Breeders Association (ANASB, Caserta, Italy). Because all buffaloes of a herd were sampled on the same test day, herd and test-day effects were confounded.

\section{Milk Protein Composition}

Contents of $\alpha_{\mathrm{S}^{-}} \mathrm{CN}, \alpha_{\mathrm{S} 2}-\mathrm{CN}, \beta-\mathrm{CN}, \gamma-\mathrm{CN}$ (which was the sum of all $\gamma$-CN fractions), $\kappa-\mathrm{CN}$, glycosylated $\kappa-\mathrm{CN}$ (glyco- $\kappa-\mathbf{C N}), \beta-\mathrm{LG}$, and $\alpha$-LA were measured using the RP-HPLC method developed by Bonfatti et al. (2008) for cow milk. An RP-HPLC chromatogram obtained from an individual buffalo milk sample is reported in Figure 1. According to Bonfatti et al. (2008), different proteins or genetic variants of a protein might have different response factors at $214 \mathrm{~nm}$. As a consequence, the same content of different proteins might provide different peak areas in the chromatogram. For this reason, $\alpha_{\mathrm{S}_{1}} \mathrm{CN} \mathrm{A}$ and $\mathrm{B}, \alpha_{\mathrm{S}_{2}} \mathrm{CN}, \beta-\mathrm{CN}, \kappa-\mathrm{CN} \mathrm{X} 1$ and $\mathrm{X} 2, \beta-\mathrm{LG}$, and $\alpha$-LA were purified from individual samples of buffalo milk with known genotype by semipreparative RP-HPLC and lyophilized to be used as calibration standards. A specific calibration equation was obtained for each protein or protein genetic variant. For $\gamma-\mathrm{CN}$, the same calibration equation of $\beta-\mathrm{CN}$ was used. Details on the analytical RP-HPLC method, as well as the description of the semipreparative method for purification of protein fractions, can be found in Bonfatti et al. (2008). A detailed description of the HPLC phenotyping and DNA genotyping of $\alpha_{\mathrm{S} 1}-\mathrm{CN}$ and $\mathrm{k}$-CN genetic variants of buffalo has been reported by Bonfatti et al. (2012).

Total casein content (TCN, g/L) was computed as the sum of $\alpha_{\mathrm{S}_{1}} \mathrm{CN}, \alpha_{\mathrm{S}^{-}} \mathrm{CN}, \beta-\mathrm{CN}, \gamma-\mathrm{CN}$, and $\kappa-\mathrm{CN}$ contents. Total whey protein content $(\mathbf{W H}, \mathrm{g} / \mathrm{L})$ was calculated as the sum of $\alpha-\mathrm{LA}$ and $\beta-\mathrm{LG}$ contents.
Protein composition (i.e., the relative proportions of protein fractions) was computed as the percentage ratio of $\alpha_{\mathrm{S}_{1}} \mathrm{CN}\left(\alpha_{\mathrm{S}^{-}} \mathrm{CN} \%\right), \alpha_{\mathrm{S}_{2}} \mathrm{CN}\left(\alpha_{\mathrm{S}^{2}} \mathrm{CN} \%\right), \beta-\mathrm{CN}(\beta-$ $\mathrm{CN} \%), \gamma-\mathrm{CN}(\gamma-\mathrm{CN} \%)$, and $\kappa-\mathrm{CN}(\kappa-\mathrm{CN} \%)$ to $\mathrm{TCN}$, as the percentage ratio of glyco- $\kappa-\mathrm{CN}$ to $\kappa-\mathrm{CN}$ (glyco- $\kappa-$ $\mathrm{CN} \%$ ), and as the percentage ratio of $\beta-\mathrm{LG}$ to $\mathrm{WH}$ ( $\beta$ $\mathrm{LG} \%$ ). As $\mathrm{WH}$ is the sum of $\alpha-\mathrm{LA}$ and $\beta-\mathrm{LG}$ contents, the percentage of $\alpha$-LA was not included because it can be derived from $\beta$-LG\%. As frequency distributions of $\gamma$-CN and $\gamma$-CN\% were not Gaussian, logarithmic transformations of $\gamma-\mathrm{CN}$ and $\gamma-\mathrm{CN} \%$ were computed $(\mathbf{L} \gamma-\mathbf{C N}$ and $\mathbf{L} \gamma-\mathbf{C N} \%$, respectively).

\section{Statistical Analysis}

Effects of environmental factors and milk yield class on milk protein composition were estimated using a linear model and the GLM procedure of SAS (version 9.2; SAS Institute Inc., Cary, NC). The linear model was

$$
y_{i j k l m}=H T D_{i}+P_{j}+D I M_{k}+M I L K_{l}+e_{i j k l m},
$$

where $\mathrm{y}_{i j k l m}$ is a measure of a trait; $H T D_{i}$ is the fixed effect of herd test day $i(i=1, \ldots, 14) ; \mathrm{P}_{j}$ is the fixed effect of parity class $j(j=1$ : first parity; $j=2$ : second and third parity; $j=3$ : fourth and fifth parity; $j=4$ : parity greater than 5 ); $D I M_{k}$ is the fixed effect of the DIM class $k(k=1$ : less than 60 DIM; $k=2$ : from 60 to $159 \mathrm{DIM} ; k=3$ : from 160 to $219 \mathrm{DIM} ; k=4$ : from 220 to 279 DIM; $k=5$ : DIM 280 or greater); MILK

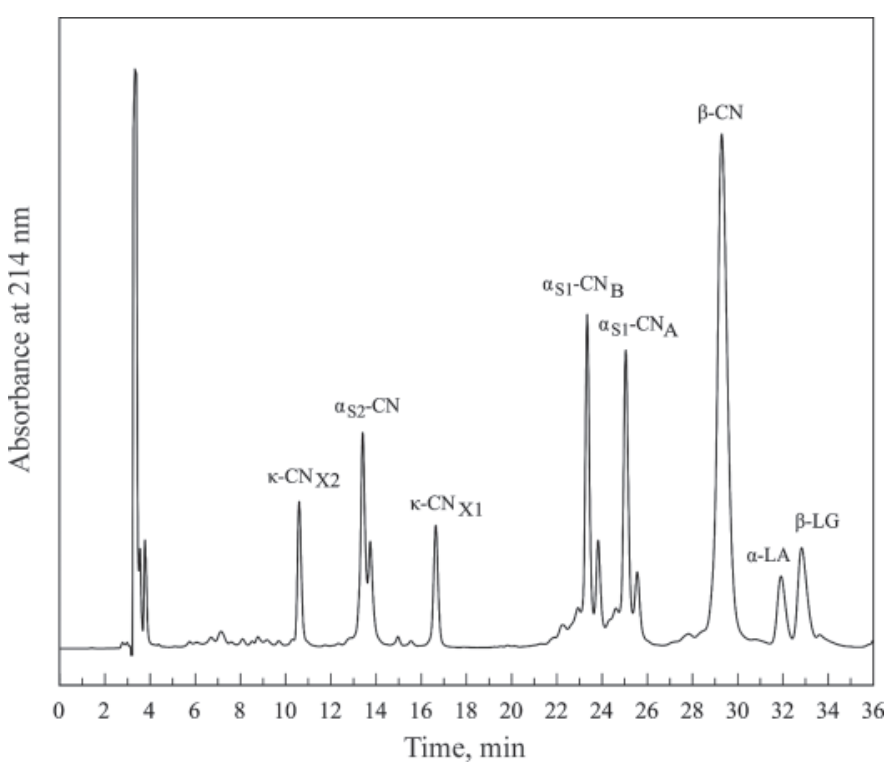

Figure 1. Example of a reversed-phase HPLC chromatogram obtained from an individual buffalo milk sample. 
Table 1. Descriptive statistics for detailed protein composition of individual samples of Mediterranean water buffalo milk $(\mathrm{n}=606)^{1}$

\begin{tabular}{|c|c|c|c|c|}
\hline Trait $^{2}$ & Mean & $\mathrm{CV}, \%$ & P1 & P99 \\
\hline TCN, g/L & 48.81 & 11.79 & 34.14 & 62.61 \\
\hline $\mathrm{WH}, \mathrm{g} / \mathrm{L}$ & 9.49 & 13.59 & 6.67 & 12.95 \\
\hline \multicolumn{5}{|c|}{ Protein fraction content, $\mathrm{g} / \mathrm{L}$} \\
\hline$\alpha_{\mathrm{S1}^{-}} \mathrm{CN}$ & 15.58 & 13.10 & 10.58 & 21.24 \\
\hline$\alpha_{\mathrm{S} 2}-\mathrm{CN}$ & 8.34 & 17.49 & 5.01 & 12.22 \\
\hline$\beta-\mathrm{CN}$ & 16.83 & 17.27 & 9.96 & 24.09 \\
\hline $\mathrm{L} \gamma-\mathrm{CN}$ & -1.46 & 34.37 & -2.84 & -0.12 \\
\hline$\kappa-\mathrm{CN}$ & 7.68 & 11.75 & 5.83 & 9.99 \\
\hline Glyco-к-CN & 2.52 & 23.54 & 1.23 & 4.06 \\
\hline$\alpha-\mathrm{LA}$ & 4.07 & 26.84 & 1.89 & 6.97 \\
\hline$\beta-L G$ & 5.42 & 17.54 & 3.52 & 8.07 \\
\hline \multicolumn{5}{|c|}{ Protein composition, \% } \\
\hline$\alpha_{\mathrm{S} 1}-\mathrm{CN} \%$ & 32.12 & 6.97 & 26.84 & 37.29 \\
\hline$\alpha_{\mathrm{S2}^{-}} \mathrm{CN} \%$ & 17.09 & 15.45 & 10.95 & 23.29 \\
\hline$\beta-\mathrm{CN} \%$ & 34.48 & 9.15 & 27.11 & 41.70 \\
\hline $\mathrm{L} \gamma-\mathrm{CN} \%$ & -0.74 & 62.34 & -2.06 & 0.53 \\
\hline$\kappa-\mathrm{CN} \%$ & 15.73 & 8.54 & 12.25 & 19.25 \\
\hline Glyco-к-CN\% & 31.81 & 20.42 & 17.04 & 47.31 \\
\hline$\beta-\mathrm{LG} \%$ & 57.11 & 15.01 & 39.87 & 75.18 \\
\hline
\end{tabular}

${ }^{1} \mathrm{P} 1$ = first percentile; P99 = 99th percentile.

${ }^{2}$ Contents of all protein fractions were measured by reversed-phase HPLC on skim milk. TCN = total casein content $=\alpha_{\mathrm{S}_{1}}-\mathrm{CN}+\alpha_{\mathrm{S} 2}-\mathrm{CN}+\beta-\mathrm{CN}+\gamma-\mathrm{CN}+\kappa-\mathrm{CN} ; \mathrm{WH}=$ whey protein $=\alpha-\mathrm{LA}+\beta$-LG; Glyco- $\kappa-\mathrm{CN}=$ glycosylated form of $\kappa-\mathrm{CN} ; \alpha_{\mathrm{S}_{1}} \mathrm{CN} \%, \alpha_{\mathrm{S}^{2}} \mathrm{CN} \%, \beta-\mathrm{CN} \%, \gamma-\mathrm{CN} \%$, and $\kappa-\mathrm{CN} \%$ are measured as percentages of TCN; Glyco- $\kappa-\mathrm{CN} \%$ is measured as percentage of $\kappa-\mathrm{CN}$ content; $\beta$-LG\% is measured as percentage of total WH content; $\mathrm{L} \gamma-\mathrm{CN}$ and $\mathrm{L} \gamma-\mathrm{CN} \%$ are logarithmic transformations of $\gamma-\mathrm{CN}$ and $\gamma-\mathrm{CN} \%$, respectively.

is the fixed effect of the milk yield class $l(l=1$ : class including the $10 \%$ low-producing buffaloes; $l=2$ : class including the $80 \%$ medium-producing buffaloes; $l=3$ : class including the $10 \%$ top-producing buffaloes); and $e_{i j k l m}$ is a random residual. Classes of DIM were defined on the basis of the estimated dynamics of milk protein percentage throughout lactation described for Mediterranean water buffalo by Catillo et al. (2002). The effects of the calving season and the interaction between parity and DIM class were also tested, but they did not significantly affect variation of any of the investigated traits and were not further considered in the model. Pearson product-moment correlations for milk protein composition were computed using the CORR procedure of SAS.

\section{RESULTS AND DISCUSSION}

\section{Descriptive Statistics}

Descriptive statistics for the investigated traits are reported in Table 1. In agreement with data reported by Catillo et al. (2002), individual milk yield ranged from 1 to $18 \mathrm{~kg} / \mathrm{d}$ and DIM ranged from 5 to 356 . The average protein content reported for Italian water buffalo (Catillo et al., 2002) and the average protein content measured by RP-HPLC differed to a large extent. This was expected and is to be primarily as- cribed to the skimming of milk before chromatographic analysis. Moreover, content of milk protein assessed by HPLC was measured in weight per volume, whereas that quantified during herd milk recording procedures was measured in weight per weight. After adjusting for skimming and specific gravity of milk, the averages of the 2 traits were comparable.

Proportions of the 4 major casein fractions were consistent with those reported by Addeo et al. (1977), Addeo (1979), and D'Ambrosio et al. (2008), but in contrast with those reported by Feligini et al. (2009). Relative contents of $\alpha$-LA and $\beta-\mathrm{LG}$ in $\mathrm{WH}$ were 42.9 and $57.1 \%$, respectively, and comparable with contents reported by Addeo and Coppola (1983), Addeo et al. (1996), and D'Ambrosio et al. (2008), but in contrast with findings by Buffoni et al. (2011). Likely, inconsistencies of results between Buffoni et al. (2011) or Feligini et al. (2009) and other studies originated from the use of commercial purified proteins from cow milk to obtain the calibration curves for HPLC quantification. When we replaced calibration equations based on buffalo milk purified proteins with equations developed through the use of cow milk proteins, averages of protein fractions contents were similar to those obtained by Buffoni et al. (2011) and Feligini et al. (2009). Because different proteins have different response factors (Bonfatti et al., 2008), the use of protein standards from cow milk to quantify buffalo milk proteins should be avoided. 
Table 2. Pearson product-moment correlations for total casein, whey protein, and milk protein composition $(\mathrm{n}=606)^{1}$

\begin{tabular}{|c|c|c|c|c|c|c|c|c|}
\hline Trait & WH & $\alpha_{\mathrm{S} 1}-\mathrm{CN} \%$ & $\alpha_{\mathrm{S} 2^{-}} \mathrm{CN} \%$ & $\beta-\mathrm{CN} \%$ & $\mathrm{~L} \gamma-\mathrm{CN} \%$ & $\kappa-\mathrm{CN} \%$ & Glyco-к-CN\% & $\beta-\mathrm{LG} \%$ \\
\hline WH & & NS & 0.17 & -0.16 & -0.09 & 0.09 & NS & -0.26 \\
\hline$\alpha_{\mathrm{S}_{1}-\mathrm{CN} \%}$ & & & -0.32 & -0.53 & 0.34 & 0.11 & 0.35 & 0.35 \\
\hline$\beta-\mathrm{CN} \%$ & & & & & -0.30 & -0.46 & -0.32 & -0.12 \\
\hline $\mathrm{L} \gamma-\mathrm{CN} \%$ & & & & & & NS & 0.26 & 0.43 \\
\hline к-CN\% & & & & & & & 0.32 & -0.18 \\
\hline
\end{tabular}

${ }^{1} \mathrm{TCN}=$ total casein content $=\alpha_{\mathrm{S} 1}-\mathrm{CN}+\alpha_{\mathrm{S} 2}-\mathrm{CN}+\beta-\mathrm{CN}+\gamma-\mathrm{CN}+\kappa-\mathrm{CN} ; \mathrm{WH}=$ whey protein $=\alpha-\mathrm{LA}+\beta$-LG; Glyco- $\kappa-\mathrm{CN}=$ glycosylated form of $\kappa-\mathrm{CN} ; \alpha_{\mathrm{S}^{-}} \mathrm{CN} \%, \alpha_{\mathrm{S}_{2}} \mathrm{CN} \%, \beta-\mathrm{CN} \%, \gamma-\mathrm{CN} \%$, and $\kappa-\mathrm{CN} \%$ are measured as percentages of TCN; Glyco- $\kappa-\mathrm{CN} \%$ is measured as percentage of $\kappa$-CN content; $\beta$-LG\% is measured as percentage of total WH content; $\mathrm{L} \gamma-\mathrm{CN}$ and $\mathrm{L} \gamma-\mathrm{CN} \%$ are logarithmic transformations of $\gamma$-CN and $\gamma$-CN\%, respectively.

\section{Correlations for the Investigated Traits}

Pearson product-moment correlations for the investigated traits are reported in Table 2. A moderate positive correlation was observed between TCN and WH. Correlations indicate that variation of protein content in buffalo milk is moderately associated with changes in casein and whey protein composition. Increased TCN in milk would result in an increased proportion of $\beta-\mathrm{CN} \%$ and in a lower proportion of all the other major casein fractions, specifically $\kappa-\mathrm{CN} \%$. However, because the correlations between TCN and $\beta-\mathrm{CN} \%$ or $\kappa-\mathrm{CN} \%$ were moderate, milks having similar TCN can still have a rather variable protein composition. This finding and known relationships between protein composition and milk coagulation properties (Wedholm et al., 2006; Bonfatti et al., 2010a) might explain why buffalo milks with similar protein content exhibit different renneting properties (Potena et al., 2001; Zicarelli et al., 2001).

Proportions of the major casein fractions were negatively correlated to each other, with $\kappa-\mathrm{CN} \%$ being the most independent. For $\kappa-\mathrm{CN} \%$, we observed a remarkable correlation only with $\beta-\mathrm{CN} \%$.

A negative correlation between $\mathrm{L} \gamma-\mathrm{CN} \%$ and $\beta-\mathrm{CN} \%$ was expected, with $\gamma-\mathrm{CN}$ being a product of $\beta-\mathrm{CN}$ proteolysis (Farrell et al., 2004; Somma et al., 2008). The proportion of $\gamma$-CN in $\mathrm{CN}$ was positively related to $\beta$-LG\%. This might be explained by the increased $\beta-\mathrm{CN}$ proteolysis occurring in milk with increased SCC (Kelly and McSweeney, 2002), which has been reported to exhibit altered WH composition (Farrell et al., 2004).

\section{Parity Effects}

Least squares means for parity effects are reported in Table 3. Parity affected the content of protein fractions as well as protein composition. Contents TCN, WH, $\alpha_{\mathrm{S} 2}-\mathrm{CN}, \beta-\mathrm{CN}$, and $\kappa-\mathrm{CN}$ decreased as parity increased. Decreased contents of all casein and whey protein fractions were observed for parity $>3$ relative to earlier parities, whereas content of glyco- $\kappa-\mathrm{CN}$ was lower for the first parity relative to following parities. Similar to casein fractions, $\mathrm{WH}, \alpha-\mathrm{LA}$, and $\beta$-LG tended to decrease when parity increased, but this variation was not statistically significant $(P>0.05)$.

No previous study investigated parity effects on buffalo milk protein composition, but our results largely agree with those reported for protein composition of bovine milk by Ng-Kwai-Hang et al. (1987). According to these authors, the content of $\alpha_{S^{-}} \mathrm{CN}$ progressively increased from the first to the third parity and decreased in later parities, $\beta-\mathrm{CN}$ decreased when parity number increased, and the sum of $\alpha_{S^{-}} \mathrm{CN}, \beta-\mathrm{CN}$, and $\kappa-\mathrm{CN}$ decreased when cows got older.

Relative contents of protein fractions showed different patterns of variation across parities. In particular, when parity increased, $\alpha_{\mathrm{S}_{2}} \mathrm{CN} \%, \beta-\mathrm{CN} \%$, and $\mathrm{L} \gamma-\mathrm{CN} \%$ tended to decrease, albeit their variations were not

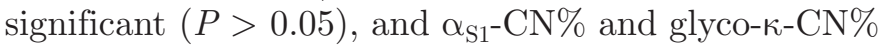
increased $(P<0.01)$. An increase in $\alpha_{S}-\mathrm{CN} \%$ and a decrease in $\beta-\mathrm{CN} \%$ when cow age increased were observed by Kroeker et al. (1985).

\section{Effects of Lactation Stage}

Least squares means of DIM class effects on the investigated traits are presented in Table 4 . In agreement with results reported by Ng-Kwai-Hang et al. (1987) for bovine milk, contents of most protein fractions exhibited the characteristic lactation dynamics observed for milk components, with high contents in early lactation, a decrease to a minimum in midlactation, and a gradual increase in the late part of lactation. Conversely, the dynamics of $\alpha$-LA, consistent with that of milk yield, exhibited a maximum between 60 and 160 DIM and then gradually decreased. Increased expression of $\alpha$-LA has been reported to correlate with higher milk production also in cow milk (Wickström et al., 2010).

The $\alpha$-LA fraction is involved in the lactose synthase complex, promoting the synthesis of lactose, which is the major osmolyte of milk (Farrell et al., 2004). Lac- 
Table 3. Least squares means $\pm \mathrm{SE}$ of parity effects on milk protein fraction contents and milk protein composition $^{1}$

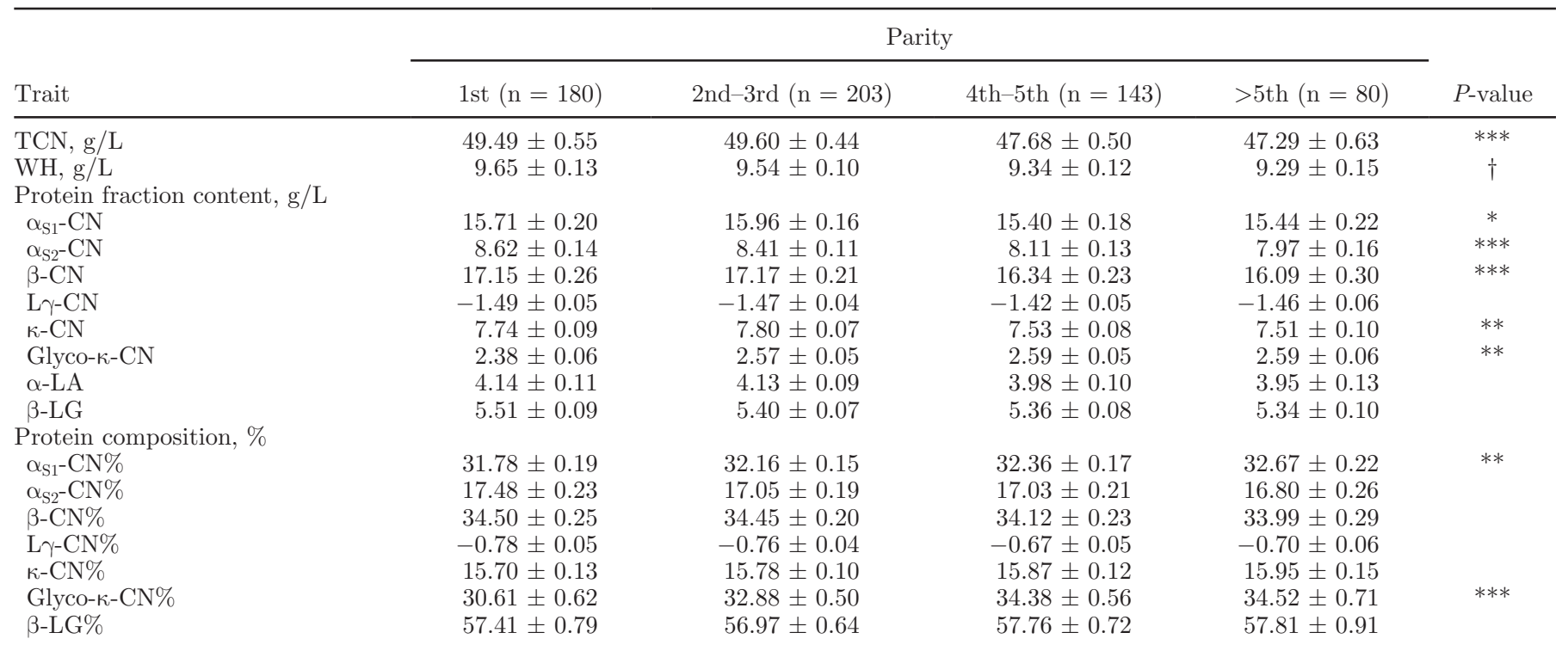

${ }^{1}$ Contents of all protein fractions were measured by reversed-phase HPLC on skim milk. TCN $=$ total casein content $=\alpha_{\mathrm{S1}^{-}} \mathrm{CN}+\alpha_{\mathrm{S} 2}$-CN + $\beta-\mathrm{CN}+\gamma-\mathrm{CN}+\kappa-\mathrm{CN} ; \mathrm{WH}=$ whey protein $=\alpha-\mathrm{LA}+\beta-\mathrm{LG} ;$ Glyco- $\kappa-\mathrm{CN}=$ glycosylated form of $\kappa-\mathrm{CN} ; \alpha_{\mathrm{S1}^{-}} \mathrm{CN} \%, \alpha_{\mathrm{S2}}-\mathrm{CN} \%, \beta-\mathrm{CN} \%, \gamma-\mathrm{CN} \%$, and $\kappa-\mathrm{CN} \%$ are measured as percentages of TCN; Glyco- $\kappa-\mathrm{CN} \%$ is measured as percentage of $\kappa-\mathrm{CN}$ content; $\beta \mathrm{LG} \%$ is measured as percentage of total WH content; $\mathrm{L} \gamma-\mathrm{CN}$ and $\mathrm{L} \gamma-\mathrm{CN} \%$ are logarithmic transformations of $\gamma$-CN and $\gamma$-CN\%, respectively.

$\dagger P<0.10 ;{ }^{*} P<0.05 ;{ }^{*} P<0.01 ; * * * P<0.001$.

tose content indirectly determines the volume of milk produced, and concentrations of $\alpha-\mathrm{LA}$ and lactose are strongly related (Wickström et al., 2010). Hence, $\alpha$-LA content is expected to be associated with milk yield.
Also milk protein fraction percentages changed throughout lactation: $\alpha_{\mathrm{S} 1}-\mathrm{CN} \%$ increased, whereas $\alpha_{\mathrm{S}^{-}}$ CN\% decreased during lactation. Conversely, Kroeker et al. (1985) reported that, in the initial 60 DIM, $\alpha_{S^{-}}$

Table 4. Least squares means \pm SE of DIM class effects on milk protein fraction contents and milk protein composition ${ }^{1}$

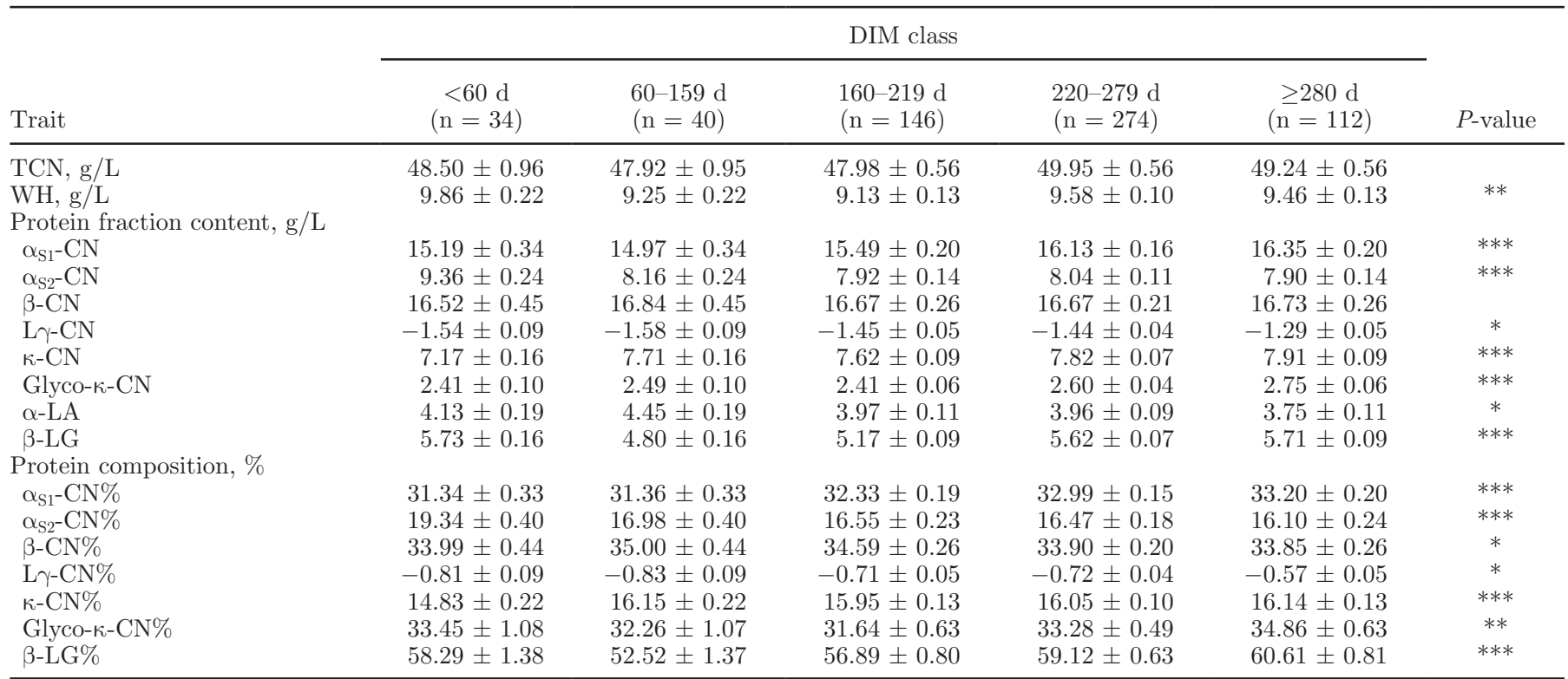

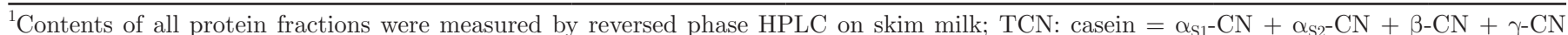
$+\kappa-\mathrm{CN}$; WH: whey protein $=\alpha-\mathrm{LA}+\beta$-LG; Glyco- $\kappa-\mathrm{CN}$ : glycosylated form of $\kappa-\mathrm{CN} ; \alpha_{\mathrm{S} 1^{-}} \mathrm{CN} \%, \alpha_{\mathrm{S} 2^{-}} \mathrm{CN} \%, \beta-\mathrm{CN} \%, \gamma-\mathrm{CN} \%$ and $\kappa-\mathrm{CN} \%$ are measured as percentages of total casein content; Glyco- $\kappa-\mathrm{CN} \%$ is measured as percentage of $\kappa$-CN content; $\beta$-LG\% is measured as percentage of total whey protein content; $\mathrm{L} \gamma-\mathrm{CN}$ and $\mathrm{L} \gamma-\mathrm{CN} \%$ are logarithmic transformations of $\gamma-\mathrm{CN}$ and $\gamma-\mathrm{CN} \%$, respectively.

${ }^{*} P<0.05,{ }^{* *} P<0.01,{ }^{* * *} P<0.001$. 
CN\% decreased dramatically with a reciprocal increase in $\beta-\mathrm{CN} \%$. In agreement with Davies and Law (1977), $\beta-\mathrm{CN} \%$ had its maximum between 60 and 160 DIM. As expected, the dynamics observed for $\mathrm{L} \gamma-\mathrm{CN} \%$ was opposite of that for $\beta-\mathrm{CN} \%$, whereas $\kappa-\mathrm{CN} \%$ reached a minimum in early lactation (DIM $<60 \mathrm{~d}$ ) and remained stable in mid and late lactation. Conversely, Kroeker et al. (1985) observed no significant change in $\kappa-\mathrm{CN} \%$ throughout lactation of dairy cows. Glycosylated $\kappa-\mathrm{CN} \%$ and $\beta-\mathrm{LG} \%$ decreased in early lactation, reached a minimum in midlactation, and increased thereafter. The largest proportion of $\alpha-\mathrm{LA} \%$ in whey protein was detected when milk yield reached its maximum and is attributable to the role of $\alpha$-LA for lactose synthesis (Farrell et al., 2004).

\section{Effect of Milk Yield}

Least squares means of milk yield class for the investigated traits are reported in Table 5. Average daily milk yield $( \pm \mathrm{SD})$ was $2.65( \pm 0.88), 6.36( \pm 1.52)$, and 11.62 $( \pm 2.16) \mathrm{kg} / \mathrm{d}$ for low-, medium-, and high-yielding buffalo classes, respectively. Significant differences in the content of $\alpha_{\mathrm{S1}^{-}} \mathrm{CN}, \beta-\mathrm{CN}, \gamma-\mathrm{CN}$, glyco- $\kappa-\mathrm{CN}$, and $\beta-\mathrm{LG}$ were detected across milk yield classes. The content of $\alpha_{\mathrm{S} 1}-\mathrm{CN}, \gamma-\mathrm{CN}$, glyco- $\kappa-\mathrm{CN}$, and $\beta$-LG significantly de- creased when milk yield increased. This is likely attributable to the dilution of milk constituents associated to the increased amount of milk yielded. A different pattern was observed for $\beta$-CN (i.e., the protein fraction most susceptible to proteolysis), which exhibited the lowest average content in the class of low-yielding buffaloes $(P<0.001)$. This result agrees with those reported by Ng-Kwai-Hang et al. (1987) for bovine milk. According to those authors, the content of all protein fractions, with the exception of $\beta-\mathrm{CN}$, correlated significantly and negatively with milk yield. It might be argued that the low-yielding group included buffaloes affected by subclinical mastitis and, as a consequence, proteolysis might have occurred more intensely in milk of those animals, resulting in a lower content of $\beta-\mathrm{CN}$ (Farrell et al., 2004).

Milk protein fraction percentages were greatly affected by the amount of milk yielded. In agreement with findings of Kroeker et al. (1985) for bovine milk, high-yielding buffaloes exhibited greater $\beta-\mathrm{CN} \%$ and lower $\alpha_{\mathrm{S1}^{-}} \mathrm{CN} \%$ relative to low-yielding animals. Moreover, milk of high-yielding buffaloes contained a greater

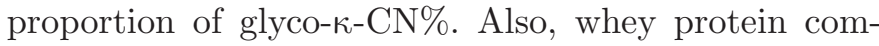
position varied across milk yield classes $(P<0.01)$, exhibiting a decrease in $\beta$-LG\% and, as a consequence, an increase in $\alpha-\mathrm{LA} \%$, when milk yield increased. This

Table 5. Least squares means \pm SE of milk yield class effects on milk protein fraction contents and milk protein composition

\begin{tabular}{|c|c|c|c|c|}
\hline \multirow[b]{2}{*}{ Trait $^{1}$} & \multicolumn{3}{|c|}{ Class of milk yield ${ }^{2}$} & \multirow[b]{2}{*}{$P$-value } \\
\hline & Low $(\mathrm{n}=121)$ & Medium $(\mathrm{n}=364)$ & $\operatorname{High}(\mathrm{n}=121)$ & \\
\hline TCN, g/L & $49.52 \pm 0.64$ & $49.27 \pm 0.43$ & $47.75 \pm 0.55$ & $\dagger$ \\
\hline $\mathrm{WH}, \mathrm{g} / \mathrm{L}$ & $9.66 \pm 0.15$ & $9.43 \pm 0.10$ & $9.27 \pm 0.13$ & \\
\hline \multicolumn{5}{|c|}{ Protein fraction content, $\mathrm{g} / \mathrm{L}$} \\
\hline$\alpha_{\mathrm{S} 1}-\mathrm{CN}$ & $16.17 \pm 0.23$ & $15.81 \pm 0.15$ & $14.90 \pm 0.19$ & $* * *$ \\
\hline$\alpha_{\mathrm{S}}-\mathrm{CN}$ & $8.30 \pm 0.16$ & $8.25 \pm 0.11$ & $8.28 \pm 0.14$ & \\
\hline$\beta-\mathrm{CN}$ & $16.10 \pm 0.30$ & $17.23 \pm 0.20$ & $16.74 \pm 0.26$ & $* * *$ \\
\hline $\mathrm{L} \gamma-\mathrm{CN}$ & $-1.36 \pm 0.06$ & $-1.50 \pm 0.04$ & $-1.52 \pm 0.05$ & $*$ \\
\hline$\kappa-\mathrm{CN}$ & $7.65 \pm 0.11$ & $7.73 \pm 0.07$ & $7.56 \pm 0.09$ & \\
\hline Glyco-к-CN & $2.77 \pm 0.07$ & $2.48 \pm 0.04$ & $2.35 \pm 0.06$ & $* * *$ \\
\hline$\alpha-\mathrm{LA}$ & $3.93 \pm 0.13$ & $4.06 \pm 0.09$ & $4.16 \pm 0.11$ & \\
\hline$\beta \mathrm{LG}$ & $5.73 \pm 0.11$ & $5.37 \pm 0.07$ & $5.11 \pm 0.09$ & *** \\
\hline \multicolumn{5}{|c|}{ Protein composition, \% } \\
\hline$\alpha_{\mathrm{S}^{-}}-\mathrm{CN} \%$ & $33.36 \pm 0.22$ & $32.15 \pm 0.15$ & $31.21 \pm 0.19$ & $* * *$ \\
\hline$\alpha_{\mathrm{S} 2}-\mathrm{CN} \%$ & $17.14 \pm 0.27$ & $16.77 \pm 0.18$ & $17.35 \pm 0.23$ & $\dagger$ \\
\hline$\beta-\mathrm{CN} \%$ & $32.99 \pm 0.29$ & $34.82 \pm 0.20$ & $35.00 \pm 0.25$ & $* * *$ \\
\hline $\mathrm{L} \gamma-\mathrm{CN} \%$ & $-0.63 \pm 0.06$ & $-0.78 \pm 0.04$ & $-0.77 \pm 0.05$ & * \\
\hline$\kappa-\mathrm{CN} \%$ & $15.86 \pm 0.15$ & $15.73 \pm 0.10$ & $15.88 \pm 0.13$ & \\
\hline Glyco-к-CN\% & $36.19 \pm 0.72$ & $32.12 \pm 0.49$ & $30.99 \pm 0.61$ & $* * *$ \\
\hline$\beta-\mathrm{LG} \%$ & $59.73 \pm 0.92$ & $57.42 \pm 0.62$ & $55.31 \pm 0.78$ & ** \\
\hline
\end{tabular}

${ }^{1}$ Contents of all protein fractions were measured by reversed-phase HPLC on skim milk. TCN $=$ total casein content $=\alpha_{\mathrm{S} 1}-\mathrm{CN}+\alpha_{\mathrm{S} 2}-\mathrm{CN}+\beta-\mathrm{CN}+\gamma-\mathrm{CN}+\kappa-\mathrm{CN} ; \mathrm{WH}=$ whey protein $=\alpha-\mathrm{LA}+\beta$-LG; Glyco- $\kappa-\mathrm{CN}=$ glycosylated form of $\kappa-\mathrm{CN} ; \alpha_{\mathrm{S} 1}-\mathrm{CN} \%, \alpha_{\mathrm{S}_{2}}-\mathrm{CN} \%, \beta-\mathrm{CN} \%, \gamma-\mathrm{CN} \%$, and $\kappa-\mathrm{CN} \%$ are measured as percentages of T-CN; Glyco- $\kappa-\mathrm{CN} \%$ is measured as percentage of $\kappa-\mathrm{CN}$ content; $\beta$-LG\% is measured as percentage of total WH content; $\mathrm{L} \gamma-\mathrm{CN}$ and $\mathrm{L} \gamma-\mathrm{CN} \%$ are logarithmic transformations of $\gamma-\mathrm{CN}$ and $\gamma$-CN\%, respectively.

${ }^{2}$ Low $=$ class including the $10 \%$ low-yielding buffaloes; medium $=$ class including $80 \%$ of buffaloes with intermediate yield; high $=$ class of the $10 \%$ high-yielding buffaloes.

$\dagger P<0.10 ;{ }^{*} P<0.05 ; * * P<0.01 ; * * * P<0.001$. 
confirms the role of $\alpha$-LA in promoting the synthesis of lactose (Farrell et al., 2004).

\section{CONCLUSIONS}

For the first time, buffalo milk protein composition was quantified in a large sample of animals and nongenetic effects due to parity, DIM, and milk yield on variation of buffalo milk protein composition were estimated. Possible effects exerted by protein genetic variants on variation of milk protein fraction contents and relative proportions should be further considered to gain a better insight into sources of variation of buffalo milk protein composition. Knowledge about factors affecting variation of milk protein composition is still scarce, and further research is needed, so that concentrations of individual proteins could be altered to meet specific requirements.

\section{ACKNOWLEDGMENTS}

The authors thank the Italian Water Buffalo Breeders Association (ANASB, Caserta, Italy) for the organization of herd sampling and for supplying milk-recording data. Filippo Di Rubbo is also gratefully acknowledged for sample collection.

\section{REFERENCES}

Addeo, F. 1979. The composition of whole water buffalo casein. Annali della Facoltà di Scienze Agrarie dell'Università di Napoli in Portici, Serie IV 13:149-159.

Addeo, F., and S. Coppola. 1983. Aspetti tecnologici e microbiologici della trasformazione del latte di bufala in mozzarella e ricotta. Il Latte 8:706-722.

Addeo, F., G. C. Emaldi, and P. Masi. 1996. Tradition and innovation in the "Mozzarella di Bufala Campana cheese" production. Proceedings of the International Symposium on Buffalo Products. EAAP Publication 82:23-39. Wageningen Pers, Wageningen, the Netherlands.

Addeo, F., J.-C. Mercier, and B. Ribadeau-Dumas. 1977. The caseins of buffalo milk. J. Dairy Res. 44:455-468.

Ariota, B., L. Milone, C. Grassi, F. Zicarelli, R. Napolano, A. Giovane, and R. Di Palo. 2009. Milk protein and cheese yield in buffalo species. Ital. J. Anim. Sci. 8:381-383.

Bonfatti, V., G. Di Martino, A. Cecchinato, L. Degano, and P. Carnier. 2010a. Effects of $\beta$-к-casein (CSN2-CSN3) haplotypes, $\beta$-lactoglobulin $(B L G)$ genotypes, and detailed protein composition on coagulation properties of individual milk of Simmental cows. J. Dairy Sci. 93:3809-3817.

Bonfatti, V., G. Di Martino, A. Cecchinato, D. Vicario, and P. Carnier. 2010b. Effects of $\beta$ - $\kappa$-casein (CSN2-CSN3) haplotypes and $\beta$-lactoglobulin $(B L G)$ genotypes on milk production traits and detailed protein composition of individual milk of Simmental cows. J. Dairy Sci. 93:3797-3808.

Bonfatti, V., M. Giantin, M. Gervaso, A. Coletta, M. Dacasto, and P. Carnier. 2012. Effect of CSN1S1-CSN3 ( $\alpha_{\mathrm{S} 1}-\kappa$-casein) composite genotype on milk production traits and milk coagulation properties in Mediterranean water buffalo. J. Dairy Sci. http://dx.doi. org/10.3168/jds.2011-4901.

Bonfatti, V., L. Grigoletto, A. Cecchinato, L. Gallo, and P. Carnier. 2008. Validation of a new reversed-phase high-performance liquid chromatography method for separation and identification of bovine milk protein genetic variants. J. Chromatogr. A 1195:101-106.

Buffoni, J. N., I. Bonizzi, A. Pauciullo, L. Ramunno, and M. Feligini. 2011. Characterization of the major whey proteins from milk of Mediterranean water buffalo (Bubalus bubalis). Food Chem. 127:1515-1520.

Catillo, G., N. P. P. Macciotta, A. Carretta, and A. Cappio-Borlino. 2002. Effects of age and calving season on lactation curves of milk production traits in Italian water buffaloes. J. Dairy Sci. 85:1298-1306.

D'Ambrosio, C., S. Arena, A. Salzano, G. Renzone, L. Ledda, and A. Scaloni. 2008. A proteomic characterization of water buffalo milk fractions describing PTM of major species and the identification of minor components involved in nutrient delivery and defense against pathogens. Proteomics 8:3657-3666.

Davies, D. T., and A. J. R. Law. 1977. The composition of whole casein from the milk of Ayrshire cows. J. Dairy Res. 44:447-454.

de Stefano, F. 2004. Economic problems in the buffalo milk filière. Vet. Res. Commun. 28:137-142.

FAOSTAT (Food and Agriculture Organization of the United Nations). 1969-2009. Agriculture statistics. Accessed May 3, 2012. http://faostat.fao.org/site/573/DesktopDefault.aspx?PageID $=573 \#$ ancor.

Farrell, H. M., R. Jimenez-Flores, G. T. Bleck, E. M. Brown, J. E. Butler, L. K. Creamer, C. L. Hicks, C. M. Hollar, K. F. Ng-KwaiHang, and H. E. Swaisgood. 2004. Nomenclature of the proteins of cows' milk-Sixth revision. J. Dairy Sci. 87:1641-1674.

Feligini, M., I. Bonizzi, J. N. Buffoni, G. Cosenza, and L. Ramunno. 2009. Identification and quantification of $\alpha_{\mathrm{S} 1}, \alpha_{\mathrm{S} 2}, \beta$, and $\kappa$-caseins in water buffalo milk by reverse phase-high performance liquid chromatography and mass spectrometry. J. Agric. Food Chem. 57:2988-2992.

Heck, J. M. L., A. Schennink, H. J. F. van Valenberg, H. Bovenhuis, M. H. P. W. Visker, J. A. M. van Arendonk, and A. C. M. van Hooijdonk. 2009. Effects of milk protein variants on the protein composition of bovine milk. J. Dairy Sci. 92:1192-1202.

ISMEA (Istituto di Servizi per il Mercato Agricolo Alimentare). 2009. Osservatorio dei prodotti DOP-IGP. Accessed May 3, 2012. http://www.ismea.it/flex/cm/pages/ServeBLOB.php/L/IT/ IDPagina/4173.

Kelly, A. L., and P. L. H. McSweeney. 2002. Indigenous proteinases in milk. Adv. Dairy Chem. 1:494-519.

Kroeker, E. M., K. F. Ng-Kwai-Hang, J. F. Hayes, and J. E. Moxley. 1985. Effects of environmental factors and milk protein polymorphism on composition of casein fraction in bovine milk. J. Dairy Sci. 68:1752-1757.

Ng-Kwai-Hang, K. F., J. F. Hayes, J. E. Moxley, and H. G. Monardes. 1987. Variation in milk protein concentrations associated with genetic polymorphism and environmental factors. J. Dairy Sci. 70:563-570.

Potena, A., C. De Filippo, D. Bove, T. Cocca, T. Haubner, and L. Zicarelli. 2001. Resa alla caseificazione e parametri reologici del latte bufalino: Risultati preliminari su latti individuali. Pages 236-240 in Proc. 1st Ital. Nat. Congr. Buffalo Breeding, Eboli, Italy.

Somma, A., P. Ferranti, F. Addeo, R. Mauriello, and L. Chianese 2008. Peptidomic approach based on combined capillary isoelectric focusing and mass spectrometry for the characterization of the plasmin primary products from bovine and water buffalo $\beta$-casein. J. Chromatogr. A 1192:294-300.

Wedholm, A., L. B. Larsen, H. Lindmark-Månsson, A. H. Karlsson, and A. Andrén. 2006. Effect of protein composition on the cheesemaking properties of milk from individual dairy cows. J. Dairy Sci. 89:3296-3305.

Wickström, E., K. Persson Waller, H. Lindmark-Månsson, and $\AA$ Sternesjö. 2010. Short communication: Relationships between $\alpha$-lactalbumin and quality traits in bulk milk. J. Dairy Sci. 93:4577-4581.

Zicarelli, L., A. Potena, C. De Filippo, R. Di Palo, and G. Campanile. 2001. Confronto tra bufale con differente resa alla caseificazione. Pages 241-246 in Proc. 1st Ital. national Congr. Buffalo Breeding, Eboli, Italy. 